Article

\title{
A Case Study in Organizing for Livable and Sustainable Communities
}

\author{
Jerry Marx * and Alison Rataj \\ Received: 29 August 2015; Accepted: 18 December 2015; Published: 23 December 2015 \\ Academic Editor: Martin J. Bull \\ Department of Social Work, University of New Hampshire, Durham, NH 03824, USA; Alison.Rataj@unh.edu \\ * Correspondence: Jerry.Marx@unh.edu; Tel.: +1-207-752-0347; Fax: +1-603-862-4728
}

\begin{abstract}
Citizens in the U.S. are making organized efforts to demand a new approach to planning urban communities, one that results in more sustainable and livable communities. The profession of social work in the U.S. once had a primary role in organizing urban residents to advocate for healthier environments in their neighborhoods. Yet, recent research documents the diminishing emphasis on community organization as an intervention method in social work. This paper offers a descriptive case study of a successful community organizing effort to promote a more livable city in Portland, Maine (USA). Data was collected by the authors using in-depth personal interviews; archival records (census data, architect models); documents (e-mails, newspaper clippings) as well as direct observation of the impacted community and development site. Implications for social work practitioners and educators involved in community organization promoting healthy communities are presented.
\end{abstract}

Keywords: community organization; social work; sustainable community development; livable communities; digital advocacy; urban planning theory

\section{Introduction}

Community organization as an intervention method in the profession of social work has a long history. Beginning in the late 1800s, social workers, nurses, and others, established nonprofit organizations called "settlement houses" in poor, inner-city neighborhoods to improve the living conditions of recent immigrants. As such, they served as vehicles for documenting the needs of community residents, organizing community services, and advocating for a healthier neighborhood environment. "Residence, research, and reform" summed up the strategy of settlement leaders, who lived in the neighborhood settlements along with recent immigrants, documented health risks, and then lobbied city government and corporations for change [1]. Public meetings, lectures, group discussion, neighborhood surveys, and direct observation were the primary communication and data collection methods employed by settlement leaders and residents. Social work pioneers, such as Jane Addams, were leaders in the settlement house movement, thereby establishing community organization as a fundamental intervention method in social work.

Recent research, however, documents the diminishing emphasis on community organization in professional social work [2,3]. There are several factors that contribute to this trend, including the lack of community organization skills among social work educators and diminishing community organization content in the social work curriculum [4]. Social work has survived as a profession in part because of its broad applicability in an ever-changing world. If community organization is to survive as a social work intervention method, then a broader, more contemporary conceptualization of community organization is needed-one that utilizes the latest technologies to address current public concerns about livable communities. 
Research in this area, particularly on the use of digital technologies in community organization as well as other types of civic and political participation, is just emerging and has shown mixed results [5-9]. With the premise that "communities" should be broadly defined as groups of people who form a distinct social unit based on location, interests, or identification, this paper offers a descriptive case study of a successful community organizing effort to promote a more livable city in Portland, Maine (USA). In so doing, the case illustrates new motivations, tactics, and technologies for community organization in social work. Data was collected by the authors using in-depth personal interviews; archival records (census data, architect models); documents (e-mails, newspaper clippings) as well as direct observation of the impacted community and development site [10].

\section{The Case of Portland, Maine}

Portland is located on the southeastern seaboard of Cumberland County in the state of Maine-about an hour drive north of Boston, MA. Once known for its manufacturing, shipping and industrial production, Portland now specializes in tourism, education and health services [11]. If its suburbs are excluded, this small city is home to 66,214 people, yet has 16 distinct neighborhoods [12]. Portland has seen a surge of urban development to accommodate an anticipated population growth as the Boston metropolitan region spreads northward up the coastline. Given it location, Portland ranked as the nation's 43rd largest hotel market, and attracted 8.1 million visitors in 2012, with tourists spending an estimated $\$ 4.1$ billion in one year [13].

However, there is another side of Portland. According to 2012 census data in Portland, $19.4 \%$ of individuals are below the federal poverty level. Finding apartments to rent in Portland has become a challenge for low and moderate income residents as well as individuals looking to relocate to the city. Vacancy rates dropped from $7.5 \%$ to approximately $2 \%$ over the last five years. The average monthly rent for a two-bedroom apartment has risen from $\$ 850$ in 2010 to over $\$ 1050$ [14]. Even though Portland boasts 17,000 rental units, more than half (58\%) of Portland residents are renters, meaning that these properties are insufficient to meet a growing demand for rental units. What is more, with 1502 houses or condos per square mile, there is not much more room to develop in the city. To partially address this need, the City of Portland made plans to add 190 market-rate units to be built by a Miami-based developer in the city's Bayside neighborhood. The city and the developer argued that this project is crucial to the city's future $[15,16]$. One group of concerned neighborhood activists disagreed.

\section{A Victim of Urban Renewal}

The neighborhood of Bayside is situated midway on a city peninsular that runs from Portland's scenic eastern neighborhood of Munjoy Hill to its fashionable "West End" neighborhood. The decline of the Bayside neighborhood began in the 1970s, when the city tore down buildings in the neighborhood to make way for the Franklin Arterial. While making it easier for suburban commuters, this highway effectively dissected the Bayside neighborhood into two parts, isolating one part of the community from the other by creating a barrier to walkability. Since then, the city has been attempting to redevelop the neighborhood but has consistently denied proposals. In 2000, the city planning department issued the "Bayside Vision", which called for more housing and larger, taller buildings in the area, including the former scrapyard in the center of the neighborhood. The plan also recognized a related need for a city-funded parking garage. In July 2011, the city agreed to sell 3.25 acres in Bayside to an out-of-state developer, Federated Companies, for \$2.3 million, with an agreement that any development would include a parking garage paid for in part with $\$ 9$ million in federal money passed through the city. In the fall of 2012, Federated unveiled their \$105 million dollar plan, subsequently referred to as the "Midtown Project" [17]. 


\section{New Urban Planning Theory}

From January 2013 until April 2013, the city held workshops on the proposed Midtown development, where "Keep Portland Livable", a group of community residents, business owners, and activists, vehemently opposed it. Based on the latest thinking in urban planning theory, the group maintained that this development would not promote a livable community. Contemporary urban planning theory has its origins in the activism and writing of Jane Jacobs, who argued that "urban renewal" was destroying the livability of urban neighborhoods. Based on her observations in Boston's North End neighborhood, New York City's Greenwich Village, and elsewhere, Jacobs argued that healthy urban communities with vitality contained densely populated neighborhoods involving short city blocks; mixed land uses (residential, business, etc.), moderately high buildings of 4-5 stories, wide sidewalks catering to pedestrians, and centrally-located parks [18]. The city of Portland has become highly attractive because it meets these characteristics. Jacobs was scoffed at by city officials and urban planners in her time, but many eventually agreed with her critique. Consequently, her theory and vision have remained highly influential in urban planning, inspiring the "New Urbanism" movement in the housing development industry [19-22].

In contrast, the Midtown development, argued neighborhood activists, was repeating the urban renewal mistakes of the past. The project would be out of scale with the building heights of the neighborhood, and with its proposed parking garages, overly auto-centric, paving the way for more cars to enter the city at the expense of residents and pedestrians. Consequently, Keep Portland Livable clashed with the city council, which held the belief that a new large-scale housing development would cure the housing crisis. Further, the state laws of Maine do not allow city taxes, so the city of Portland is heavily dependent on property taxes. One way to raise funds, therefore, is to push out nonprofits, and bring in big developments. This combined with the project's now archaic use of urban design would lead to negative consequences for the city of Portland, argued Keep Portland Livable. More precisely, opponents warned that the developer's proposal featured high rise towers that would destroy site lines, cast significant shadows, and generate dangerous wind tunnels. In addition, the project lacked sufficient open space and sidewalks [22].

With respect to building height, according to city building code regulations in Bayside, buildings are not to exceed the zone's current 125-foot height limit; the new development's height, however, would need to be 165 feet. Consequently, in April of 2013, the Portland City Council voted to grant a building height exemption for the massive project. Prior to the meeting, Keep Portland Livable published an advertisement in the city's major newspaper, the Portland Press Herald, alerting the public to the mammoth size of the proposed project and to the fact that the City Council would be voting to grant a height exemption. At the City Council Meeting on 22 April 2013, after having spent thousands of dollars to run the awareness ad, only a handful of people showed up to support Keep Portland Livable. Consequently, the Portland City Council approved the zoning height amendment [23].

After the zoning decision, Keep Portland Livable realized that the city wanted this project to move forward, regardless of existing city regulations. These community activists knew they would need sophisticated support to effectively oppose the development. Consequently, in April 2013, Keep Portland Livable retained a land-use attorney who attended all of the future city planning board workshops related to the Midtown project. Then, in August 2013, the group hired a communications consultant to aid in public relations, media campaigns and awareness strategies.

With the support of their communications consultant, in September of 2013, Keep Portland Livable hired a polling firm, Public Policy Polling, to conduct a 500-person phone poll of Portland residents regarding the Midtown project. Results showed that after completing the questionnaire, $30 \%$ of respondents were in favor of the development, $54 \%$ were opposed, and $16 \%$ were unsure. Given this documentation of public opposition, the group's lead organizers decided to increase their advocacy efforts [22]. 
In October of 2013, Keep Portland Livable publicly launched its website, Facebook page, LinkedIn and Twitter accounts. The group's leaders used technology as a strategy to help build stronger public opposition to the Bayside project. In addition, the organizers reached out to friends and affiliates to pitch in and show up at meetings. They developed list of names of Bayside residents and potential donors, then e-mailed letters to these people about the Bayside project. As a result, Keep Portland Livable began to see a steady increase in supporters.

The group also mounted a media campaign in which it sent out press releases to TV stations, public radio and newspapers. Furthermore, the leaders of Keep Portland Livable scheduled informal house parties where they presented a PowerPoint slideshow about the problems surrounding the Midtown Project. Since all neighborhoods in Portland have a neighborhood organization, they were able to meet with community residents from all parts of the city in hopes of mounting a rally of support [24].

The first planning board public hearing was scheduled for December 2013. Keep Portland Livable began to ready their constituents by sending out flyers and talking points. Additionally, up to this point, the developer had gotten away without showing any images of what the towers would look like. To address this, Keep Portland Livable hired an architect to make digital renderings, using Google Earth, of what these towers would actually look like in Portland. The group then had these images printed and put on large easels right as people walked into the planning board meeting. Their strategy worked. At the first planning board public hearing, the council chambers were packed with a big turnout of Midtown opponents.

The second planning board public hearing was scheduled for January 2014. In a classic trick, the developer packed the council chambers early in the day with construction workers from around the region. Nonetheless, there was still a strong turnout from the opponents of the Bayside Project, who were educated and prepared with more talking points. However, the opposition was not enough and the planning board approved the Bayside project [23].

On 12 February 2014, Keep Portland Livable announced its legal appeal to the planning board approval of the Midtown Project. Grounds for the appeal centered on the project's failure to comply with the city's comprehensive plan and land use ordinances as well as the lack of planning board authority to approve the more than 20 significant waivers granted from city standards and codes. This opposition and advocacy by Keep Portland Livable effectively slowed the development process to a halt, giving time for other Portland residents and business owners to realize the project's full implications. Fearing rising construction costs, mounting citizen anger, and the ultimate demise of its project, Federated Companies, the Miami development company, in October of 2014, conceded to the community activists' demands and pledged to work with Keep Portland Livable and the city to lower the height and general scale of the project along the lines proposed by Keep Portland Livable. More specifically, the plan was scaled back from its original proposal for two 14-story towers and two parking garages. The revised proposal involved four six-story buildings and just one parking garage [23]. As it turned out, the community organizers and supporters of Keep Portland Livable proved that you can fight city hall.

\section{Conclusions}

The case of Portland's Bayside neighborhood and Keep Portland Livable provides several important lessons for social worker practitioners and educators involved in community organization, and specifically, the promotion of healthy communities.

\subsection{Keep Portland Livable Was a Technological Movement}

The group's lead organizers made effective use of new technologies to rapidly mobilize opposition to the Midtown project as originally designed. Given that the group, Keep Portland Livable, did not exist before the Midtown project was announced, organizers were able to quickly educate and mobilize Portland residents by constructing a website (700 signups for updates and 
action alerts), establishing a Facebook page (525 likes), and a Twitter account (over 100 followers). E-mail and LinkedIn were also used extensively. In a small city, this level of community participation is significant [25].

The effectiveness of using Facebook and other new technologies such as Twitter to organize social action activities has been demonstrated by the Occupy Wall Street movement and public protests against police violence in U.S. minority communities. Given this track record and appeal to young people, such technologies need to be emphasized as part of community intervention methods in social work education and utilized extensively by social workers in community organizing.

\subsection{Keep Portland Livable Represented an Online Community}

It can be argued that Keep Portland Livable was, to a large extent, a "community" based on location. Yet, although the Bayside neighborhood was the battlefront for community organizers, the community residents that followed and supported this organizing effort actually resided in various neighborhoods of Portland as well as outlying suburbs. They did not represent the traditional case of neighbors living on the same street or block or even same neighborhood. For example, the community organization model often used in traditional social work education is Jane Addams and Hull House, which was an inner-city settlement house strategically located within walking distance of the train station in the midst of a poor immigrant neighborhood in Chicago. As previously described, community organizers resided in the settlement house, which, in turn, was the primary vehicle for communication and organizing. Most community discussion took place at this meeting place in the neighborhood.

In contrast, Keep Portland Livable was not a traditional geographic community of neighbors helping neighbors, but, more accurately, an online community of shared vision and values. Most communication and organizing were done electronically. Many members of Keep Portland Livable had witnessed the mistakes of traditional urban planning, whether in Portland or elsewhere, and therefore, subscribed to the promise and values inherent in contemporary urban planning theory and its vision of healthier cities. What is more, it is argued here that a broader conceptualization of community, one that transcends geographic location, to emphasize shared vision and values involving what characterizes healthy community environments, enhances the opportunity for attracting support (volunteers and donations) from outside the community. In this digital advocacy age, that support can extend worldwide.

\subsection{Keep Portland Livable Reflected a Desire for a Greener, Sustainable Community}

This shared vision of the community organizers, as stated, was for a more sustainable, livable community. The prevention of global warming and preserving a healthy environment are increasingly primary interests of the general public, and, therefore, represent a core issue for future community organization by social workers and others. In fact, concern for the environment is a tradition in Maine, given its economic dependence on natural resources [26]. Research has shown that the "greenest" communities are densely populated urban areas where dwellings are built vertically, recreation areas are shared by many, and residents use bicycles, public transportation, or their legs for commuting [27]. The Midtown project, particularly as envisioned by community activists in this case, promotes these characteristics.

\subsection{Keep Portland Livable Was a Network of Professional Specializations}

The core group of community organizers in this case was actually small. Although it began with several people, the driving force behind the organizing effort consisted of just two concerned Portland residents, a local architect and an organizational development consultant. However, Keep Portland Livable was able to raise funds to hire several other specialized professionals as needed. As stated earlier, the group enlisted the services of a land-use attorney to attend city Planning Board meetings. This helped to better inform public opposition to the project, counter the technical 
expertise of Portland's city government, and provide credibility to the group's effort. In addition, Keep Portland Livable hired a communications consultant and polling consultants to assist with a media campaign, surveys, and other public education strategies. Furthermore, Keep Portland Livable hired an architect to make digital renderings, using Google Earth, of what the proposed Midtown project towers would actually look like in Portland. The group displayed these graphic images on its website and at city planning board meetings. The lesson for future community organization is that neighborhood organizations and activist groups should not rely just on community volunteers in order to prevent or promote community change. The technical expertise of those in power needs to be matched to the fullest extent by community residents and organizers. Sometimes, neighborhood volunteers can supply this expertise, but, at times, professionals need to be enlisted.

This study is limited by its single-case design. The authors encourage further case studies of successful community organizing to promote sustainable, livable communities. Such studies might then be generalized in relation to new urban planning theory. More importantly for social work, this research would also serve to inform macro social work education as well as social workers engaged in community organization.

Acknowledgments: The authors would like to acknowledge the contributions to this paper of community organizers Tim Paradis and Peter Monro.

Author Contributions: Both authors contributed equally to this manuscript.

Conflicts of Interest: The authors declare no conflict of interest.

\section{References}

1. Jerry D. Marx. Social Welfare: The American Partnership. Boston: Allyn \& Bacon, 2004.

2. Robert Fisher, and Danielle Corciullo. " Rebuilding community organizing education in social work." Journal of Community Practice 19 (2011): 355-68. [CrossRef]

3. Jack Rothman. " Education for Macro Intervention: A Survey of Problems and Prospects." ACOSA, 2012. Available online: https://www.acosa.org/joomla/pdf/RothmanReportRevisedJune2013 (accessed on 21 December 2015).

4. Shane R. Brady, and Mary Katherine O'Connor. " Understanding how community organizing leads to social change: The beginning development of formal practice theory." Journal of Community Practice 22 (2014): 210-28. [CrossRef]

5. Shane R. Brady, Jimmy A. Young, and David A. McLeod. "Utilizing digital advocacy in community organizing: Lessons learned from organizing in virtual spaces to promote worker rights and economic justice." Journal of Community Practice 23 (2015): 255-73. [CrossRef]

6. Sujin Choi, and Han Woo Park. " An exploratory approach to a Twitter-based community centered on a political goal in South Korea: Who organized it, what they shared, and how they acted." New Media $\mathcal{E}$ Society 16 (2014): 129-48. [CrossRef]

7. Sanne Kruikemeier, Guda van Noort, Rens Vliegenthart, and Claes H. de Vreese. " Unraveling the effects of active and passive forms of political Internet use: Does it affect citizens' political involvement? " New Media $\mathcal{E}$ Society 16 (2014): 903-20. [CrossRef]

8. Daniela V. Dimitrova, Adam Shehata, Jesper Stromback, and Lars W. Nord. " The effects of digital media on political knowledge and participation in election campaigns: Evidence from panel data." Communication Research 41 (2014): 95-118. [CrossRef]

9. Terri L. Towner. " All political participation is socially networked? New media and the 2012 election." Social Science Computer Review 31 (2013): 527-41. [CrossRef]

10. Robert K. Yin. Case Study Research: Design and Methods, 4th ed. Thousand Oaks: Sage Publications, 2009.

11. Charles S. Colgan. The Maine Economy: Yesterday, Today and Tomorrow. Portland: Brookings Institution Metropolitan Policy Program, University of Southern Maine, 2006.

12. U.S. Census Bureau. " State and County Quick Facts: Portland (City) Maine, 2014." Available online: http:/ / quickfacts.census.gov/qfd/states/23/2360545.html (accessed on 6 June 2014). 
13. Steve Law. "More Tourists Put Portland at Top of Travel Plans. 2014." Available online: http://portlandtribune. com/pt/9-news / 208913-65990-more-tourists-put-portland-at-top-of-travel-plans (accessed on 6 June 2014).

14. Randy Billings, and Staff Writer. "Rental Demand in Portland is through the Roof. 2013." Available online: http://www.pressherald.com/2013/04/28/ rental-demand-in-portland-is-through-the-roof_2013-04-29/ (accessed on 11 June 2014).

15. City Data. Portland, Maine. Available online: http://www.city-data.com/city/Portland-Maine.html (accessed on 11 June 2014).

16. Keep Portland Livable. About Us. Available online: http://keepportlandlivable.com/About_us.html (accessed on 6 June 2014).

17. Randy Billings. “Portland Approves \$105 Million 'Midtown' Project. 2014." Available online: http://www. pressherald.com/2014/01/14/portland_approves_105_million_midtown_project_/ (accessed on 6 June 2014).

18. Jane Jacobs. The Death and Life of Great American Cities. New York: Random House, 1961.

19. Leigh Gallagher. The End of the Suburbs: Where the American Dream Is Moving. New York: The Penguin Group, Inc., 2013.

20. New Urbanism. "Creating Livable Sustainable Communities (2013). 2013." Available online: http:/ / www.newurbanism.org/ (accessed on 6 June 2014).

21. Ruth Fincher. "Urban redevelopment in Boston: Rhetoric and reality." In Conflict, Politics and the Urban Scene. Edited by Kevin R. Cox, and Ronald John Johnston. New York: St. Martin's Press, 1982.

22. Peter Monro. " Bayside Vision vs. Midtown." Keep Portland Livable, 2014.

23. David Carkhuff. " Midtown project in Bayside scaled down, per settlement." The Portland Sun, 24 October 2014. Available online: http://www.portlanddailysun.me/index.php/newsx/local-news/ 13150-midtown-project-in-bayside-scaled-down-per-settlement (accessed on 21 December 2015).

24. Keep Portland Livable. “Threats Foreseen to Portland's Ideal Future. 2015." Available online: http:// keepportlandlivable.com/threats-foreseen-to-portlands-ideal-future/\#more-674 (accessed on 29 August 2015).

25. Tim Paradis, and (Keep Portland Livable, Portland, ME, USA). Personal communication, 30 December 2014.

26. Colin Woodward. The Lobster Coast: Rebels, Rusticators, and the Struggle for a Forgotten Frontier. New York: Penguin Group, 2005.

27. David Owen. Green Metropolis: Why Living Smaller, Living Closer, and Driving Less Are the Keys to Sustainability. New York: Penguin Books, 2009.

(C) 2015 by the authors; licensee MDPI, Basel, Switzerland. This article is an open access article distributed under the terms and conditions of the Creative Commons by Attribution (CC-BY) license (http:/ / creativecommons.org/licenses/by/4.0/). 